\title{
ANALYSIS OF APPROACHES TO ESTABLISHING CRITERIA FOR ASSESSING THE VIABILITY OF THE ENTERPRISE
}

\author{
Bugai V.Z., Gorbunova A.V. \\ Zaporizhzhia National University \\ Ukraine, 69600, Zaporizhzhia, Zhukovsky str., 66 \\ bugai_v_z@ukr.net, gor_an_v@ukr.net \\ ORCID 0000-0002-3568-1577, ORCID 0000-0001-6450-4740
}

Key words:

survivability, viability, enterprise, methodical approach, remediation potential, remediation capacity.
In the current critical conditions of state management, many domestic enterprises are on the verge of survival. Therefore, the issue of assessing its level is relevant, which allows us to determine in advance the main factors that contribute to the deepening of such a negative process in order to develop and implement appropriate measures. It is grounded that the algorithm of determining the level of enterprise viability includes the assessment of remediation potential and evaluation of remediation capabilities. It is established that the assessment of the level of rehabilitation potential and rehabilitation capacity of the enterprise based on the analysis of the dynamics of a limited number of indicators does not take into account its systemic nature, and therefore has significant limitations. A significant part of the proposed methods is not allocated and does not quantify the impact of threats on the level of remediation capacity of enterprises. Therefore, it is advisable to take into account the degree of risk of transition from a satisfactory financial condition to a state of the financial crisis in terms of relevant factors. In the considered approaches to the assessment of the level of viability of the enterprise, the main attention is paid to the assessment of the level of remediation potential and remediation capacity in retrospective and current dimension, which does not provide complete information about the prospects of enterprise development. It was found that to assess the remediation potential, most researchers suggest taking into account mostly indicators that characterize the financial sphere of the enterprise but they are effective and do not allow to determine what is the root cause of the crisis in the enterprise. It is substantiated that the assessment of threats to the viability of the enterprise should be carried out not only in cases of economic difficulties but also in order to anticipate, avoid, effectively and efficiently use the remediation potential.

\section{АНАЛІЗ ПІДХОДІВ ДО ВСТАНОВЛЕННЯ КРИТЕРІЇВ ОЦІНЮВАННЯ ВИЖИВАННЯ ПІДПРИЕМСТВА}

\author{
Бугай В.3., Горбунова А.В. \\ Запорізький начіональний університет \\ Україна, 69600, м Запоріжжя, вул. Жуковського, 66
}

\begin{abstract}
Ключові слова:
виживання, життєздатність, підприємство, методичний підхід, санаційний потенціал, санаційна спроможність.
\end{abstract}

В сучасних кризових умовах господарювання багато вітчизняних підприємств перебувають на межі виживання. Тому актуальним є питання оцінки iii рівня, що дозволяе завчасно визначити основні чинники, що сприяють поглибленню такого негативного процесу з метою розроблення і реалізації відповідних заходів. Обгрунтовано, що алгоритм визначення рівня життєздатності підприємства включає оцінку санаційного потенціалу і оцінку санаційної спроможності. Встановлено, що оцінка рівня санаційного потенціалу і санаційної спроможності підприємства на основі аналізу динаміки обмеженої кількості індикаторів не враховує системного iii характеру, а відтак, має суттєві обмеження. У значній частині пропонованих методів не виділяється і кількісно не визначається вплив загроз на рівень санаційної спроможності підприємств. Тому доцільно враховувати міру ризику переходу із задовільного фінансового стану у стан фінансової кризи у розрізі відповідних чинників. У розглянутих підходах до оцінки рівня життєздатності підприємства основну увагу приділяють оцінці рівня 
санаційного потенціалу і санаційної спроможності у ретроспективному і поточному вимірі, що не дає повної інформації про перспективи розвитку підприємства. Встановлено, що для оцінки санаційного потенціалу більшість дослідників пропонує брати до уваги здебільшого показники, що характеризують фінансову сферу діяльності підприємства, проте вони $\epsilon$ результативними й не дають можливості визначити, що є першопричиною виникнення кризи на підприємстві. Обгрунтовано, що оцінку загроз життєздатності підприємства необхідно проводити не тільки у випадках економічних труднощів, але й для того, щоб їх передбачати, уникати, ефективно та раціонально використовувати санаційний потенціал.

\section{Statement of the problem}

In modern crisis conditions of management the system of viability represents the generalized model of the economic actions directed on support of stable and effective work of all divisions of the enterprises in the conditions of economic threats, which constantly arise, both from internal, and external factors of environment by development of methods of prediction of negative tendencies, implementation of anti-crisis measures at enterprises in order to increase their competitiveness and efficiency.

The formation of a viability system is becoming increasingly important, because in market conditions, companies must constantly prevent crises and timely develop and implement measures to prevent bankruptcy, independently determine the range and volume of production, the nature of relations with suppliers and consumers, credit, investment, innovation, dividend policy, etc. In addition, the formation of such a system will allow such business entities: to identify in a timely manner prone to financial insolvency; develop and implement anti-crisis measures; use available resources effectively; prepare for sudden changes in the external environment; identify the basic needs of the market; identify and use favorable environmental conditions; improve coordination and control. However, despite the availability of a significant number of methodical approaches to assessing the viability of enterprises, today there are no clearly defined criteria and a system of indicators on the basis of which effective decisions could be made to assess the remediation potential and the possibility of remediation measures. At the same time, the issue of timely diagnosis of financial and economic problems in enterprises and early detection of the need for remediation procedures is extremely important for domestic business entities, as the share of unprofitable ones remains consistently high, and the problem of their survival is particularly relevant.

\section{Analysis of recent studies and publications}

In-depth attention to the problem of assessing the level of productivity of enterprises has been paid by such domestic scientists as T. Bulovich [1], L. O. Ligonenko [2], O. Z. Tsar [3], O. A. Lisinchuk [4], T. M. Bilokon [5], K. V. Bagatska [6], S. Perederieva [7] and others.

Scientists note that an objective assessment of the viability of the enterprise is the basis for making informed management decisions about its operation and development. In their research, they note that each method has its own conditions and limits of application. Most scientists believe that determining the level of viability of the enter- prise should be based on the following algorithm: analysis of remediation potential; assessment of remediation capacity and possibilities of its survival. All researchers note that there is a link between the viability of the enterprise and the provision of financial resources.

\section{Objectives of the article}

The aim of the article is to study methodical approaches to assessing the level of viability of industrial enterprises, identifying their advantages and disadvantages and forming conclusions about the feasibility of their use in the practice of assessing the viability of corporate structures.

\section{The main material of the research}

Studies show that one of the categories used to characterize the company's ability to survive is "remediation potential" - a system of financial, labor, production, innovation resources, reserves and existing and hidden opportunities for their use, which can be used to form a sufficient level of remediation capacity, which, in turn, is a prerequisite for effective remediation [8].

The analysis of literature suggests that both partial and integral indicators are used to assess the level of remediation potential.

Thus, in the source [3] the system of indicators that characterizes the financial potential includes five groups of indicators that characterize the property status; liquidity and solvency; financial stability; profitability and profitability; business activity of the enterprise.

To assess the production potential, the following quantitative indicators were selected: the coefficient of accumulation of equipment wear; sales volume compared to the base year; return on assets; costs per 1 UAH of products; capital adequacy; fixed assets renewal ratio; the ratio of the real value of fixed assets in the property of the enterprise.

Qualitative indicators include: suitability of equipment; the level of technological equipment of the enterprise; technological aging of equipment; functional aging; economic aging of equipment.

In order to determine the level of organizational potential, the following quantitative indicators were used in the analysed research work: labour productivity; total administrative costs versus base year; payroll versus base year; annual payroll per employee; total financial performance of the enterprise per employee.

The author also includes assessment of qualitative indicators: planning at the enterprise, controlling systems, financing systems at the enterprise, investment systems, determination of the quality of personnel policy. 
Here, in our opinion, it is worth giving the following remarks:

- separate indicators (coefficient ratio of receivables and payables; period of repayment of receivables and payables; ratio of financial leverage; coefficient of financial autonomy) - are closely interrelated, which in calculating the level of rehabilitation potential can lead to distortion of results;

- the results of the calculation of quality indicators, which are based on expert evaluation, are quite subjective;

- the controlling system is used in a rather limited circle of domestic enterprises, so the author's recommendations, in fact, have no practical significance.

Researcher O.A. Lisnichuk to the remediation potential includes the following components: financial potential; personnel and management potential; production potential; investment-innovation potential; marketing potential [4].

When assessing the financial component of the rehabilitation potential of the enterprise, she proposes to use the following indicators:

1) financial assets, equity, sales proceeds, cash flows from operating activities, net income - indicate the presence of financial resources of the enterprise, as well as sources of their reproduction;

2) indicators of business activity, profitability - characterize the ability of the enterprise to use resources efficiently and provide them due to this growth in the future;

3 ) indicators of liquidity and solvency, the share of working capital of the enterprise, the ratio of net cash flow to assets - characterize the ability of the enterprise to maintain normal and stable operation from the standpoint of ensuring financial stability.

When assessing the personnel and management component of the remediation potential the scientist focuses on assessments of the quality and stability staff, such as overall staff turnover and turnover among managers. These indicators, in her opinion, are indicators of trust in the company by its employees and management, and therefore it is clear that the greater the loyalty of staff, the higher the potential for overcoming the crisis in its activities.

The level of the production component of the remediation potential of the enterprise, according to the author, is evidenced by the following factors: the level of wear of production equipment; the cost of production in the dynamics and the share of fixed costs; the level of capital stock of labor at the enterprise and the percentage of production equipment related to the 5 th or 6 th technological modes.

Indicators of the innovative component of the remediation potential are the share of innovative products in total production, the level of enterprise costs to finance innovation, the share of value added in the structure of the final price of products, as well as its coefficient competitiveness.

Assessing the marketing component of the remediation potential, the paper proposes the following indicators: sales volume and market share of the enterprise in the dynamics; the share of marketing and sales costs in total sales and per $1 \%$ of market share; the share of sales to regular customers of the enterprise (the stability of its customers) and the profitability of its sales [4].

Regarding the author's suggestions on the choice of factors for assessing the remediation potential of the enterprise, we believe that the following remarks should be made:

- the purpose of rehabilitation measures of the enterprise, which is in crisis, is not only to restore its solvency but also to create conditions for its successful financial and economic activities in the long run. therefore, in our opinion, the financial component of the rehabilitation potential should include indicators that affect the formation of financial stability of the enterprise;

- regarding the factors that, in the author's opinion, form the production potential, we note that to obtain objective results of such indicators as nominal and actual production capacity of the enterprise, the level of wear of production equipment, nominal and actual productivity of production equipment, we believe is problematic;

- we believe that the cost of production of the enterprise should be attributed to the financial component of the remediation potential. the share of fixed costs in the structure of production costs can be largely formed by financial factors (interest on the loan, rent, depreciation deductions).

According to the source [9], currently the share of the 5 th structure in Ukraine is less than 5\% of total production, and the 6th structure is absent.

Summarizing the existing experience in the practice of assessment and analysing the methods of determining the remediation potential, we can conclude that they mostly take into account the indicators that characterize the financial sphere of the enterprise, but they are effective and do not allow to determine the root cause of the crisis enterprise.

Research shows that after assessing the remediation potential, they begin to determine the remediation capacity of the enterprise in crisis. However, in the scientific literature there is no single point of view on the methodical approach to its evaluation

Thus, scientist T.M. Bilokon in her work proposed an express method for assessing the rehabilitation capacity of the sugar industry [5]. At the same time, financial remediation capacity and economic remediation capacity are distinguished.

Within the framework of financial remediation capacity, the calculation of the following indicators is proposed: coverage ratio, equity ratio, ratio of receivables and payables, coefficient of autonomy, profitability of product sales, profitability of all activities, turnover ratio of accounts payable, receivables turnover, capital turnover ratio.

Regarding the assessment of economic rehabilitation capacity of sugar industry enterprises, the following indicators are proposed: raw material base, coefficient capacity utilization rate, availability of management staff and key specialists, production duration, share of fuel cost in production costs, competition, share of unclaimed claims by creditors, possibility of receivables collection. Investors' proposals.

However, the researcher does not justify how to assess the overall level of remediation capacity of the enterprise.

We find the approach to assessing the remediation capacity suggested by T.V. Bulovych is more constructive. Bulovich proposes to use such indicators as market share, employee productivity, the efficiency of capital, depreciation ratio of fixed assets, the profitability of fixed assets, Biver coefficient, financial leverage ratio, maneuverability ratio, 
absolute and total liquidity ratios, turnover ratio of accounts payable and receivable, and the transformation ratio [1].

The researcher proposed to calculate the integral coefficient of remediation capacity of the enterprise as a geometric average of partial integral coefficients: marketing potential of the enterprise; labour potential; production potential; financial potential.

Thus, analysing the presented methodologies for assessing the remediation capacity of enterprises, the following conclusions can be made:

1) Most of the above methodologies are based on determining the indicators of financial and economic activity of the enterprise. This assessment is quite informative but does not provide the possibility to identify trends of the enterprise development. To obtain realistic results, remediation capacity should be evaluated systematically, examining the dynamics of indicators that characterize its elemental composition;

2) The indicators that characterize the financial sphere of the enterprise activity are taken into consideration most of the time, but they are effective and do not allow us to identify what is the root cause of the crisis in the enterprise. In our opinion, to assess the remediation capacity, it is necessary to analyse the dynamics of indicators that characterize the condition, provision, and efficiency of all factors of production;

3) The information base for using these methods is the statistical reporting of the enterprise. Taking into account the dynamics of economic conditions in the country and the specificity of filling them in most enterprises, it is difficult to obtain reasonable results;

4) None of the proposed methodologies provides complete information about the prospects for enterprise development. Assessment of remediation capacity of the enterprise is carried out only from the standpoint of determining the phase of the crisis and the probability of bankruptcy.

We consider remediation capacity as a current assessment of the enterprise ability to survive and develop effectively in the future. Moreover, in our opinion, the assessment of the remediation capacity should be based on the assessment of the enterprise potential, i.e. on the identification of possibilities and reserves for its further effective functioning, and for this purpose, it is necessary to take into account key elements of potential, their quantitative and qualitative characteristics.

Professor L.O. Ligonenko proposes a methodical approach, based on the following criteria, for the assessment of the enterprise viability [2]:

1. The presence of net assets $-\mathrm{L} 4$;

2. The availability of assets to ensure the fulfilment of obligations to repay borrowed capital and to ensure the required level of liquidity of assets - L3;

3. Ensuring financial sustainability, i.e. the ability to generate cash inflows in time and amount sufficient to finance cash outflows related to the enterprise operational and investment activities - L2;

4. Ensuring break-even operation of the enterprise - L1.

The level of enterprise viability is determined based on compliance with the following ratios of these parameters (Table 1).
Table 1 - The state of enterprise viability depending on the ratio of its parameters

\begin{tabular}{|c|c|c|c|c|}
\hline \multirow{2}{*}{ State of viability } & \multicolumn{4}{|c|}{ Parameters of viability } \\
\cline { 2 - 5 } & L1 & L2 & L3 & L4 \\
\hline Full viability & $\geq 0$ & $\geq 0$ & $\geq 0$ & $\geq 0$ \\
\hline Efficiency crisis (hidden crisis) & $<0$ & $\geq 0$ & $\geq 0$ & $\geq 0$ \\
\hline Solvency crisis & $<0$ & $<0$ & $\geq 0$ & $\geq 0$ \\
\hline $\begin{array}{c}\text { Debt settlement crisis (bankruptcy } \\
\text { threat, financial insolvency) }\end{array}$ & $<0$ & $<0$ & $<0$ & $\geq 0$ \\
\hline Bankruptcy & $<0$ & $<0$ & $<0$ & $<0$ \\
\hline
\end{tabular}

Source: according to [2]

The disadvantages of this approach to assessing the viability of the enterprise, in our opinion, include the following: no specific indicators are pointed; the assessment criteria have a very general meaning. Therefore, this approach is more theoretical than practical.

It should be noted that the researcher N.P. Karachina proposes to use the indicator of profitability as the ratio of profit from the main activity (PMA) to profit before taxation (PBT) to assess the level of enterprise viability. Depending on the ratio between these two indicators, the scientist identifies the following types of profitability: viable $(\mathrm{PMA}>0$, $\mathrm{PBT}>0$ ); encouraging $(\mathrm{PMA}>0$, PBT $<0$ ); illusory (PMA $<0$, $\mathrm{PBT}>0$ ); unpromising $(\mathrm{PMA}<0, \mathrm{PBT}<0)$ [10].

We believe that this proposition has a rather theoretical significance because the financial capabilities for the development of the enterprise do not depend on the revenue structure but on its total amount, which is aimed at replenishing the equity of the enterprise.

The research allows us to formulate this interrelation of remediation potential, remediation capacity, and viability of the company (Fig. 1).

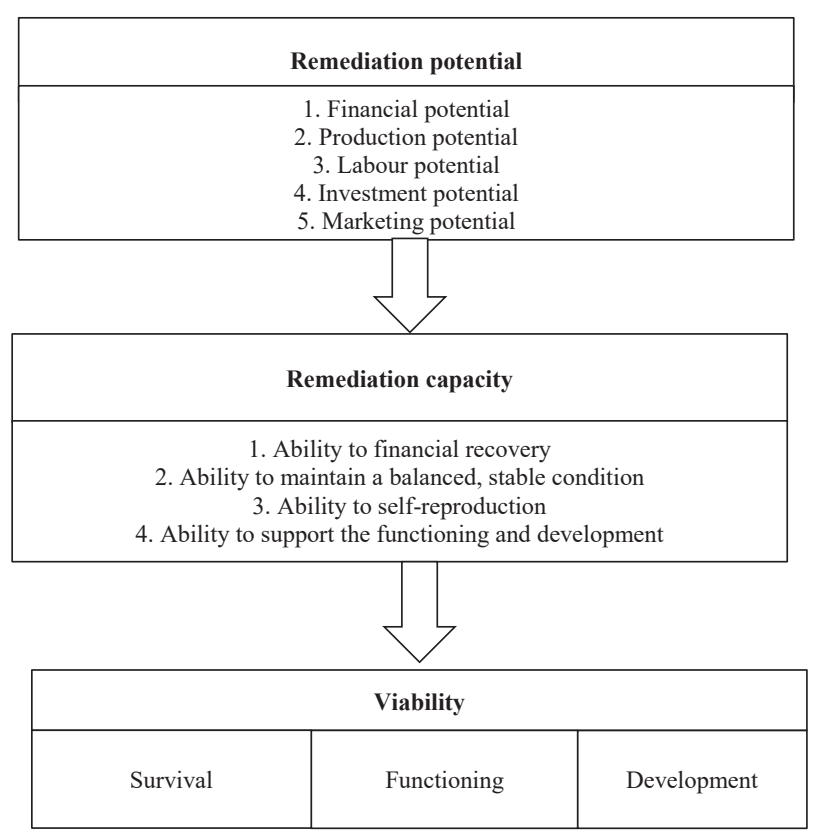

Fig. 1 Relationship between remediation potential, remediation capacity, and viability of the enterprise. Source: according to $[1 ; 7 ; 11]$ 


\section{Conclusions}

The analysis of scientific works on the researched problem testifies to the following:

- the assessment of the sustainability level of the company is carried out according to the following algorithm: assessment and analysis of the remediation potential; assessment and analysis of the remediation capacity;

- the assessment of the level of remediation potential and remediation capacity of the enterprise based on the analysis of the dynamics of a limited number of indicators does not take into account its systemic nature, and therefore has significant limitations;

- a significant part of the proposed methods is not identified and quantifies the impact of threats to the level of remediation capacity of enterprises. Therefore, it is advisable to take into account the degree of risk of transition from a satisfactory financial condition to a state of financial crisis due to the same factors;

- the reviewed approaches to the assessment of the level of the enterprise viability focus on the assessment of the level of remediation potential and remediation capacity in retrospective and current measurements. None of the proposed methodologies provides complete information about the prospects for the enterprise development. Assessment of remediation capacity of the enterprise is carried out only from the standpoint of determining the phase of the crisis and the probability of bankruptcy;

- the analysed methodologies for determining the remediation potential allow us to conclude that they mainly take into account the indicators that characterize the financial sphere of the enterprise, but they are effective and do not allow us to identify what is the root cause of the crisis in the enterprise.

\section{References}

1. Bulovich T.V. (2009). Upravlinnia sanatsiinoiu spromozhnistiu pidpryiemstva yak peredumova yoho vyzhyvannia [Management of remediation capacity of an enterprise as a prerequisite for its survival]. Visnyk Khmelnytskoho natsionalnoho universytetu - Bulletin of Khmelnitsky national university, 4 (2), 161-167. [in Ukrainian].

2. Ligonenko L.O. (2000). Antykryzove upravlinnia pidpryiemstvom teoretyko-metodychni zasady ta praktychnyi instrumentarii [Anti-crisis management of an enterprise: theoretical and methodological principles and practical tools]. Kyiv [in Ukrainian].

3. Tsar O.Z. (2017). Finansova sanatsiia subiektiv hospodariuvannia v ekonomitsi Ukrainy [Financial remediation of business entities in the economy of Ukraine]. Candidate's thesis. Lviv [in Ukrainian].

4. Lisnichuk O.A. (2016). Finansove upravlinnia sanatsiinoiu spromozhnistiu pidpryiemstv Ukrainy [Financial management of remediation capacity of Ukrainian enterprises] Candidate's thesis. Irpin [in Ukrainian].

5. Bilokon T.M. (2008). Orhanizatsiino ekonomichnyi mekhanizm sanatsii pidpryiemstv kharchovoi promyslovosti [Organizational and economic mechanism of remediation of food processing enterprises] Extended abstract of candidate's thesis. Kyiv [in Ukrainian].

6. Bagatska K.V. (2005). Problemni pytannia vyznachennia sanatsiinoi spromozhnosti pidpryiemstv [Problems of determination of remediation capacity of enterprises]. Derzhava ta rehiony - State and regions, ser: Economics and enterprise, 1, 56-62 [in Ukrainian].

7. Perederiyeva S. (2011). Kryterii otsinky sanatsiinoho potentsialu pidpryiemstva-borzhnyka [Criteria for evaluating the remediation potential of a borrower enterprise]. Ekonomichnyi Analiz - Economical Analysis, issue 9, part 3, 233-236 [in Ukrainian].

8. Larionova K., Donchenko T. (2012). Formuvannia sanatsiinoho potentsialu yak instrumentu upravlinnia sanatsiieiu pidpryiemstv lehkoi promyslovosti [Formation of remediation potential as an instrument of management of remediation of enterprises of light industry]. Sotsialno-ekonomichni problemy i derzhava-Socio-Economic Problems and State, issue 2 (7), 38-47. Retrieved from http://sepd.tntu.edu.ua/images/stories/pdf/2012/12lklplp.pdf [in Ukrainian].

9. Fedorova Y.V. (2016). Perspektyvy innovatsiinoho rozvytku Ukrainy: tekhnolohichni uklady [Prospects for innovative development of Ukraine: technological arrangements]. Visnyk Khmelnytskoho natsionalnoho universytetu - Bulletin of Khmelnitsky national university. Economical Sciences, 1, 123-126 [in Ukrainian].

10. Karachina N.P. (2010). Ekonomichna povedinka mashynobudivnykh pidpryiemstv: teoriia, metodolohiia, praktyka upravlinnia [Economic behavior of machine-building enterprises: theory, methodology, management practice]. Vinnitsya : Kniga-Vega [in Ukrainian].

11. Lisnichuk O.A. (2012). Rozrakhunok sanatsiinoho potentsialu pidpryiemstva zarubizhnyi dosvid ta vitchyzniana praktyka [The calculation of remediation potential of the enterprise: foreign experience and domestic practice]. Innovatsiina ekonomika - Innovative economy, 5 (31), 51-56 [in Ukrainian]. 